\title{
VARIOUS ASPECTS OF THE GENESIS AND PERSPECTIVES ON AGRICULTURAL BROWNFIELDS IN THE CZECH REPUBLIC
}

\author{
Jan SKÁLA, Jarmila ČECHMÁNKOVÁ, Radim VÁCHA, Viera HORVÁTHOVÁ
}

\begin{abstract}
Abandoned agricultural objects from the period of large-scale agricultural production in the socialist era represent a peculiar topic in the former communist countries of Eastern Europe, surpassing the experience of the EU15 countries or USA that have extensive and long-standing practice in brownfields redevelopment. The question of brownfields resulting from the transformation of the agricultural sector during the transition period of the Czech Republic is presented in this paper. Agricultural brownfields are the most frequently occurring brownfields in the Czech Republic (especially in some regions), but their area share is much lower, indicating their spatial disposition in the landscape. Some aspects of agricultural brownfields regeneration, including possibilities of its funding, are discussed in the paper. We also deal with geographical, environmental and historical aspects of the existence of these localities in the Czech Republic in the context of potential financial resources and possibilities for funding their revitalization.
\end{abstract}

\section{Shrnut}

\section{Vybrané aspekty vzniku a možností využití zemědělských brownfields v České republice}

Problematika dědictví areálů socialistické zemédělské velkovýroby je fenoménem postsocialistických zemí a částečně se vymyká zkušenostem EU15 či USA, které maji dlouholeté a bohaté zkušenosti s nástroji revitalizace lokalit typu brownfield. Článek je zaměřn na problematiku zemědělských brownfields, které jsou di̊sledkem transformace zemědělství v postsocialistických zemích. Opuštěné zemědělské areály jsou nejčastějším typem brownfields v České Republice, avšak jejich plošní podíl je mnohem menší, což poukazuje na jejich prostorové uspořádání v krajině. $V$ př́spěvku jsou diskutovány vybrané aspekty revitalizace zemědělských brownfields včetně možností financování. Diskutovány jsou geografické, environmentální, historické aspekty existence těchto lokalit na území České republiky v souvislostech potencionálních informačních zdrojů a dále v návaznosti na možnostech financování revitalizace.

Key worlds: agricultural brownfields, revitalization, rural development, Czech Republic

\section{Introduction}

The topic of brownfields used to be related to urban and city lands, but due to political and economic changes in Eastern Europe brownfields resulted not only from industry but also from activities characteristic of rural sites (agriculture, closeddown facilities providing rural services - consumer cooperatives, provincial houses of culture, etc.). The period of political-economic transformation brought many changes into the agricultural sector of Eastern Europe. The transition to a market economy had to involve radical reconfiguration of land resources in the former socialist countries: changes in property rights (Lerman, 2004; Bartůšková, Homolka, 2009), as well as changes in land use patterns (Baumann, 2011; Bičík et al., 2001; Müller, 2009). The property rights changed and various land allocation and privatization strategies affected agricultural performance in the transition years (Lerman, 2004). Cropland abandonment became a widespread change in land use patterns in the postsocialist era in Eastern Europe and European Russia (Bičík et al., 2001; Ioffe et al., 2004; Prishchepov et al., 2012). Various regional studies reported and in some cases quantified the major drivers of agricultural land abandonment (Baumann, 2011; Müller, 2009; Prishchepov et al., 2013). Statistical models showed that ecological conditions (soil type, elevation) and socio-economic characteristics (rural population change, industrialization and mechanization rate, urbanization rate, unemployment) can explain the spatial heterogeneity of farmland abandonment. The relative influence and relations of these variables in 
post-socialist farmland abandonment may regionally differ and generalization across countries is scarcely possible (Bauman et al., 2011; Müller, 2009). Benayas et al. (2007) reviewed the main problems and opportunities related to agricultural land abandonment. In the consequences of radical reconfiguration of land resources in the former socialist countries, some agricultural facilities lost their function (Svobodová, Věžník, 2009).

Specific statistical data to quantify the number of abandoned farm buildings, however, are lacking across Europe. The decrease of agricultural enterprises is demonstrated to be a widespread structural change in European agriculture (Verhoeve et al., 2012; Jaarsma, de Vries, 2013). Jaarsma and de Vries (2013) used the decrease in the number of farm enterprises 1990-2007 (dairy farming in six EU countries) as a rough estimate of the number of abandoned farm buildings. The inheritance of the objects of large-scale socialist agriculture surpasses the experience of western countries that have extensive and long-standing practice in brownfields redevelopment. Whereas abandoned farm buildings are a consequence of the enlarging scale of agriculture in Western Europe (Jaarsma, de Vries, 2013), the transformational shift from collective to individual agriculture was attended by general downsizing of corporate farms in Eastern Europe (Leerman, 2004). Large farm sizes and collective organization of production sharply distinguished socialist agriculture from the agriculture in market economies, and this common heritage of agricultural production suggested a fairly uniform conceptual framework for agricultural reform in all transition countries (the former socialist countries in Europe and Central Asia) (Leerman, 2004). The framework determined the specific conditions for the abandonment of agricultural buildings and their future evolution. The processes of transformation from collective to individual agriculture in Eastern Europe occurred against the backdrop of macro-scale driving forces of global trade liberalization, joining agrarian policies such as the European Common Agricultural Policy (Doucha, Foltýn, 2008; van Meijl, 2006) and of new understandings of the countryside and its functions (Noe et al., 2008).

The topic of brownfields in urban areas is widely discussed in many countries; however, the topic of agricultural brownfields is at the edge of research interest. The problem of agricultural brownfields is neglected for many reasons: the marginal interest of developers (Hudečková, 1995) or problematic projects contrary to the needs and interests of municipalities; a scanty attention by research teams (city planners, geographers, economists); peripheral location; and commonly small-scale area size and low environmental loads (as compared with industrial or military brownfields). However, they can represent a serious problem for rural regions, considering the size and developing potential of the involved sites. Agricultural brownfields are usually located near a settled area and open landscape interface and in some cases in the open. Agricultural buildings belong to the dominating features of settlements and rural landscape; this is why the situation of agricultural estates can markedly affect the urban and landscape character (Mackovič, 2003). Their progressive deterioration eventually leads to their complete state of disrepair (Garcia and Ayuga, 2007), and the idled and desolated agricultural objects become a negative element in the rural landscape disturbing the landscape pattern as well as the architectural character of villages.

Spatial planning for rural brownfields in Europe is geared to questions of preserving the cultural heritage of traditional agricultural buildings (Garcia and Ayuga, 2007; Taasia), to diversification potential and acceptability of non-agrarian functionalities in the countryside (Verhoeve et al., 2012), or to land protection potential of rural brownfields revitalization (Garcia, Ayuga, 2007). The issue of the duality between traditional and modern agricultural buildings (duality between architectural and aesthetic quality and economic aspects), observed across Europe (Fuentes et al., 2010; Ruda, 1998; Tassinari et al., 2010), is greatly manifested in the former socialist countries (especially in terms of material, shape and technology unification of building collective farms with poor landscape consistency).

The topic of brownfields is usually linked with ecological risks and brownfields become a synonym for environmental load. Environmental hazards are widely discussed in the topic of industrial brownfields because the nature of the environmental load is significantly determined by the mode of former industrial production (Page, Berger, 2006), and economic impacts of the ecological burdens of urban brownfields are well documented (Howland, 2004; Schoenbaum, 2002). Agricultural brownfields can pose serious environmental hazards in some cases. The risks can follow from former area utilization: storage of potentially hazardous material (preparations for plant protection, pesticides, fertilizers, petroleum and oil products storage); spillage of liquids from agricultural machines; unsuitable agricultural waste treatment; or from activities following the object abandonment - illegal dumps, hazardous waste storage. The ecological burdens of obsolete pesticide storage sites have been documented from various localities (Dvorská et al., 2012). 


\section{Material and methods}

The problem of brownfields was tackled based on various potential information sources. A general insight into agricultural brownfields in the Czech Republic was gained from the Research Study for Localization of Brownfields in the Territory of the Czech Republic (2007) conducted by Czechinvest (Investment and Business Development Agency of the Czech Republic). However, the Czechinvest study targeted all brownfield types (except for mining areas) and only brownfields more than 1 ha in size were studied. Agricultural brownfields are often small areas or idle parts of larger areas. This indicates that other potential information sources should be used to complement the issue of agricultural brownfields. The Czechinvest (2007) study was used to analyze the regional structure of brownfields on various regional scales - meso-regional, micro-regional and local. For the micro-regional analysis, brownfield data were used for small districts ${ }^{1}$ from three administrative regions (Ústí, Vysočina and Pardubice).

The local study of agricultural brownfields was based on the identification of brownfields using orthophotomaps and the LPIS (Land Parcel Identification System). The local study was made in three districts of model regions. We investigated the evolution of agricultural facilities from the chronological sequence of orthophotomaps (available for 2003, 2006, 2011 at: www.mapy.cz) and using the database of agricultural facilities from LPIS (agricultural buildings not included in the LPIS database, whose evolution was indicated as brownfields succession, were marked as potential brownfields - see Fig. 1). Supplementary information sources were used for the identification of potential agricultural brownfields - especially the Contaminated Sites Database System ("Systém evidence kontaminovaných míst" (in Czech) - available at: www.sekm.cz) covering the potentially contaminated sites and the "Database of extinct villages" (available at: www.zanikleobce. cz) with valuable information targeting, among other things, historical farm yards and granges. The Czechinvest (2007) agricultural brownfield localities were revised for their actual condition in three case studies of districts using the LPIS database and the chronological sequence of orthophotomaps. Revitalised former brownfields were analyzed to elucidate common driving forces of the revitalization process. The methodology of using various remote sensing data was used for the identification of non-registered agricultural brownfields to supplement the existing information sources.

\section{Results and discussion}

The Research Study for Localization of Brownfields conducted by Czechinvest revealed some 2,355 brownfield localities in the Czech Republic (2007). The total area of identified brownfields is 10,362 ha. However, the total number of brownfields is estimated to be between 8,500 and 11,700, and an estimated total area of these localities is $27,000-38,000$ ha. Although the emergence of brownfields was first put into the public eye with the restructuring of the industrial sector, the Czechinvest study (2007) showed that the most

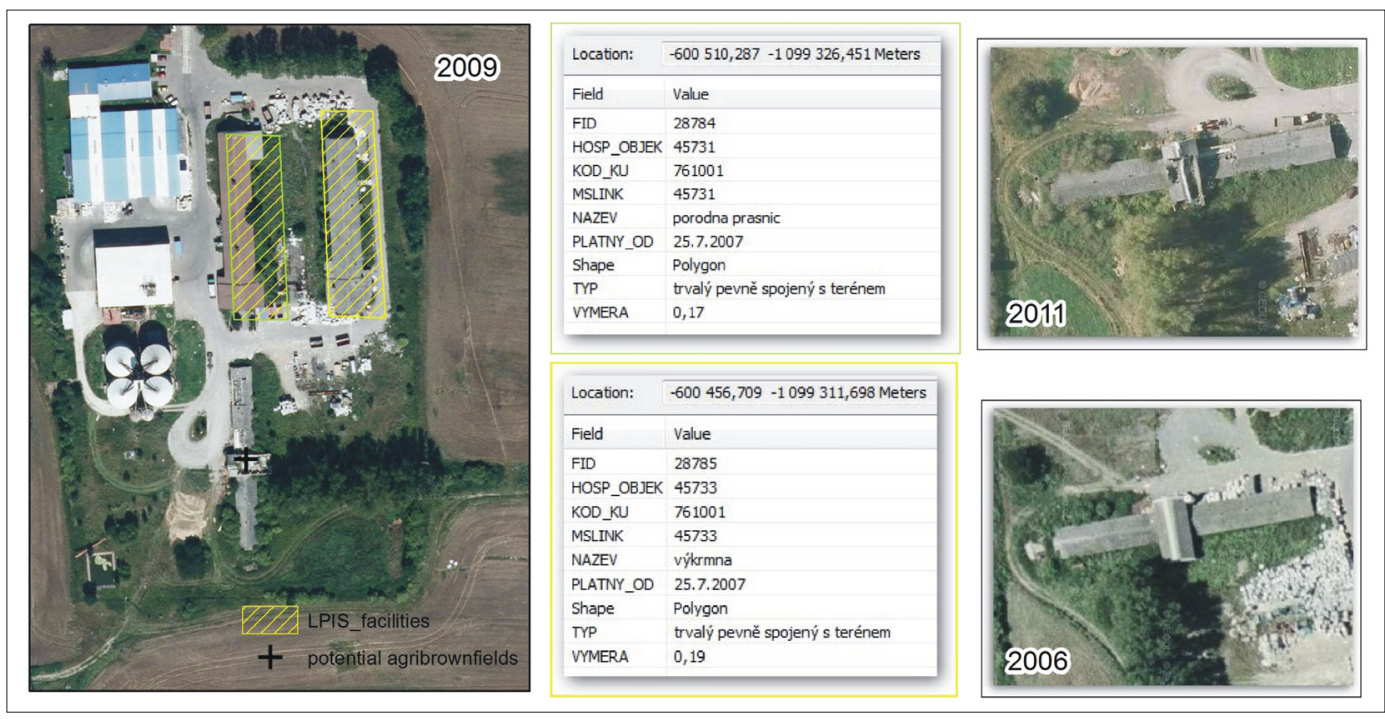

Fig. 1: Visualisation of methodology framework for the identification of potential agricultural brownfields using various information sources

\footnotetext{
${ }^{1}$ Municipalities with Extended Competence (obce s rozšířenou působností; also third-level municipalities, unofficially also called "small districts" which took over most of the administration of the former district authorities
} 
frequently occurring type is represented by brownfields that came into existence after the transformation of the agricultural sector $(34.9 \%)$, whereas their area proportion is half $(17.8 \%)$. This indicates that the agricultural brownfield sites are very frequent but cover a small area (compared to industry or military brownfields in Fig. 1). According to Czechinvest (2007), about one half of the brownfields (48.6\%) are located in municipalities with up to 2,000 inhabitants (simplified definition of rural area) in the Czech Republic.

\subsection{Regional differentiation aspects of agricultural brownfields in the Czech Republic}

The socioeconomic transformation period after 1989 brought many changes into the agricultural sector in the Czech Republic. The transformation impacts were regionally conditioned as well (Věžník and Bartošová 2004; Bičík and Jančák 2005). Proportions of regional brownfields follow the structural characteristics of the region and the impacts of transformation processes. The regional scrutiny of the brownfields (Fig. 2) shows that the Olomouc and Zlín Regions have the highest proportional share of agricultural brownfields, exceeding 50\%. The Plzeň, Pardubice and Vysočina Regions have about a half share. In typically industrial regions (Karlovy Vary, Liberec and Moravian-Silesian), the agricultural brownfields are rare.

The micro-regional and local differentiation of agricultural brownfields is depicted in Figs. 3-5. The micro-regional study based on small districts data from the Czechinvest study (2007) indicates a high geographical variation of agricultural brownfields. The geographical variation can follow geographical conditions for agriculture (see Fig. 3 for the Ústí Region) with a distinct differentiation of small districts between mountainous and coal field areas, and small districts along the boundary with the Region of Central Bohemia with suitable conditions for agriculture and traditional agricultural production (hops, cereals). The regional differentiation of agricultural brownfields in the Pardubice Region follows the differences between urban and rural parts of the region. The lowest share of agricultural brownfields was in districts with traditional manufacturing industries (Hlinsko, Vysoké Mýto, Lanškroun) and in small mountain districts (Králíky, Žamberk). A higher share of agricultural brownfields was in districts with favourable conditions for agriculture and outside urban areas - Přelouč, Holice, Polička (see Fig. 4).

The regional structure of agricultural brownfields in the Vysočina Region (Fig. 5) is more complicated; however, extremes in the share of agricultural brownfields were found in small districts, where the ratio was deformed by low data availability - Humpolec (only two brownfields), Náměšt nad Oslavou (three brownfields) and Světlá nad Sázavou (two). A higher proportion of agricultural brownfields was in districts with favourable conditions for agriculture (Moravské Budějovice, Třebíč, Velké Meziřičí) and in the traditional agricultural district of Pelhrimov with the production of potatoes.

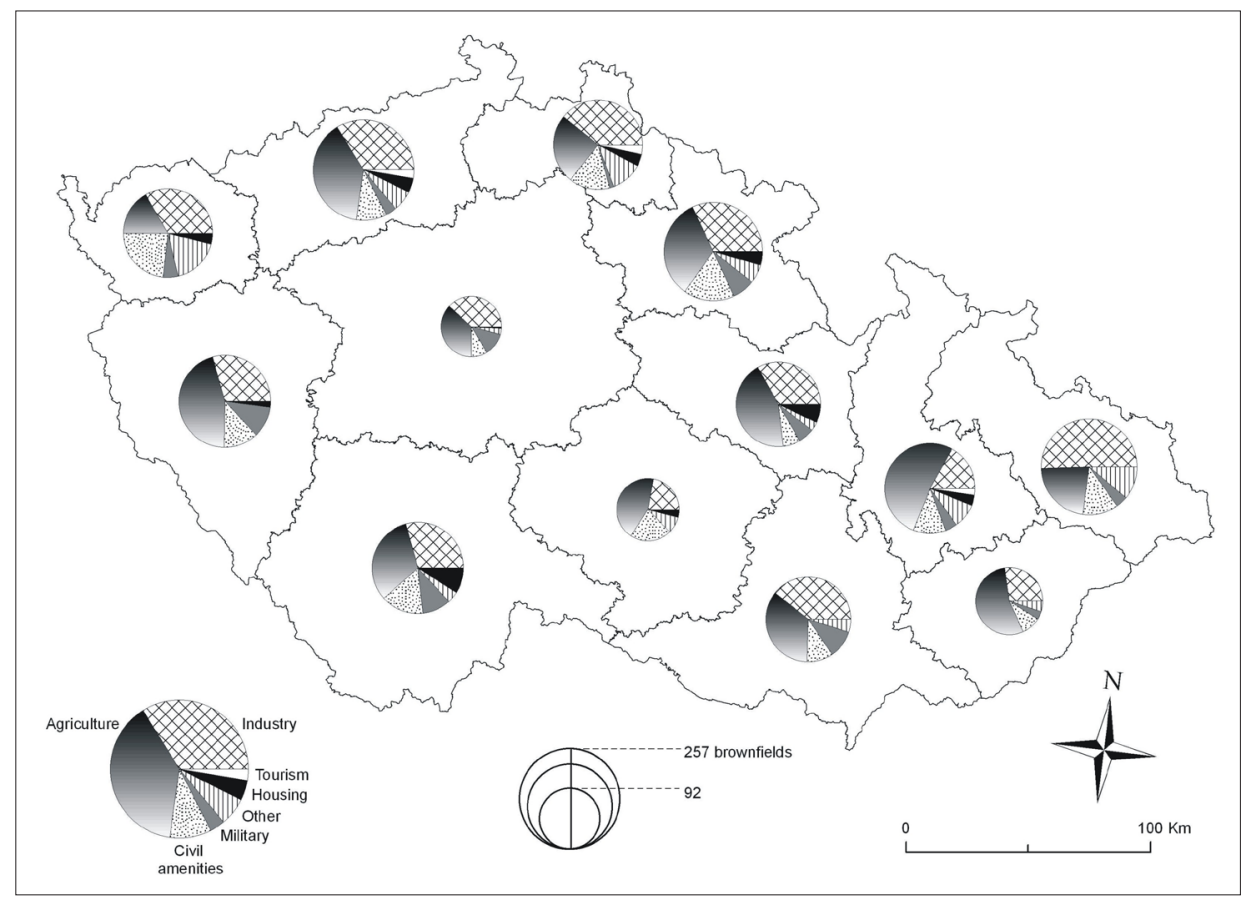

Fig. 2: Regional scrutiny of the composition of brownfields according to their former use Data source: Czechinvest (2007) 
However, the strategy for the reclamation of agricultural brownfields is primarily embedded in the programmes of rural development. Regional Operational programmes can better reflect the composition of regional brownfields and hence urgency of redevelopment and priorities for each region. Spatial location seems to be a significant factor for the redevelopment potential and possibilities. Possibilities of revitalization and interests of municipalities can significantly differ in different geographical locations.

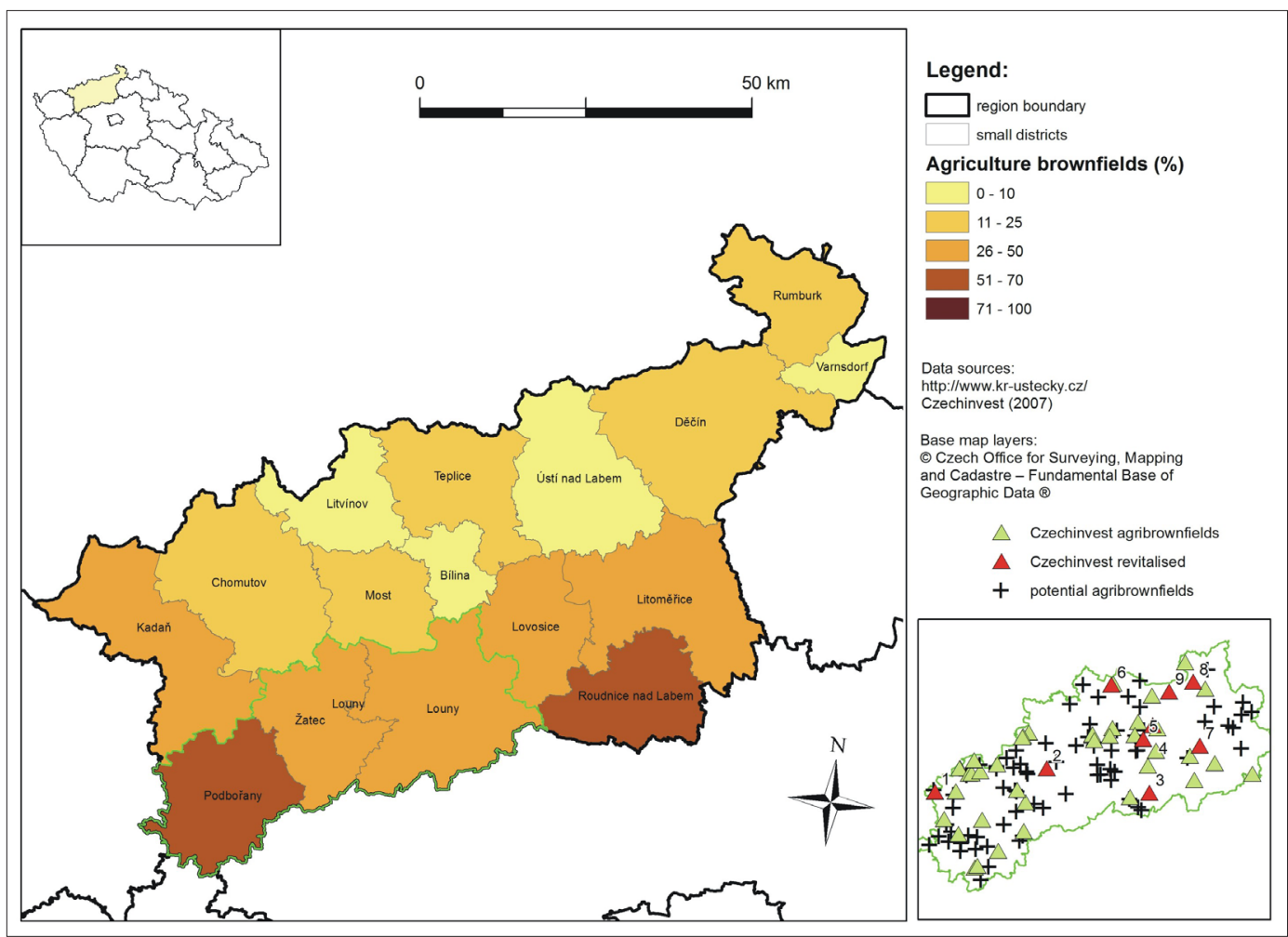

Fig. 3: Micro-regional and local differentiation of agricultural brownfields in the Ústí Region

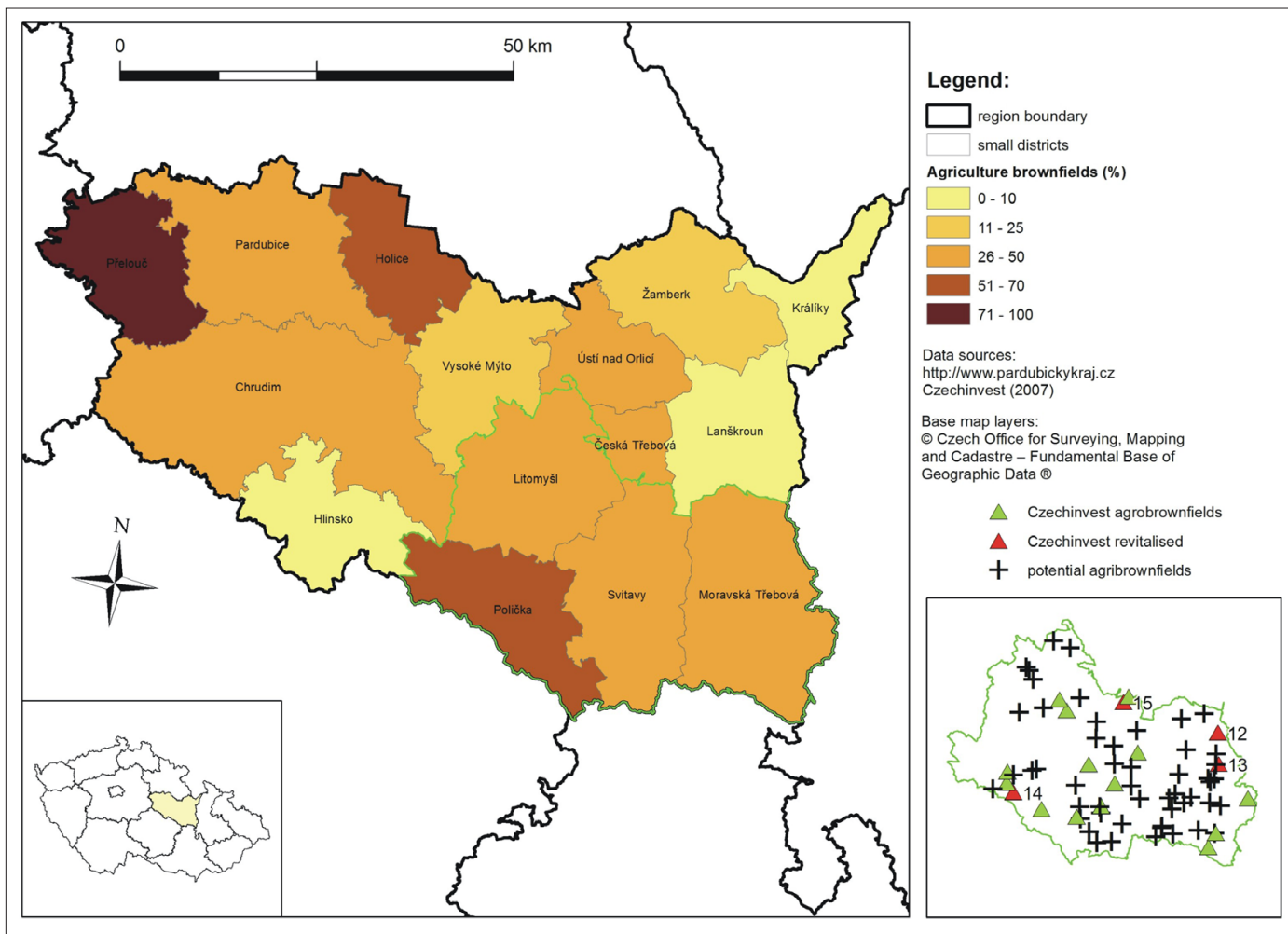

Fig. 4: Micro-regional and local differentiation of agricultural brownfields in the Pardubice Region 


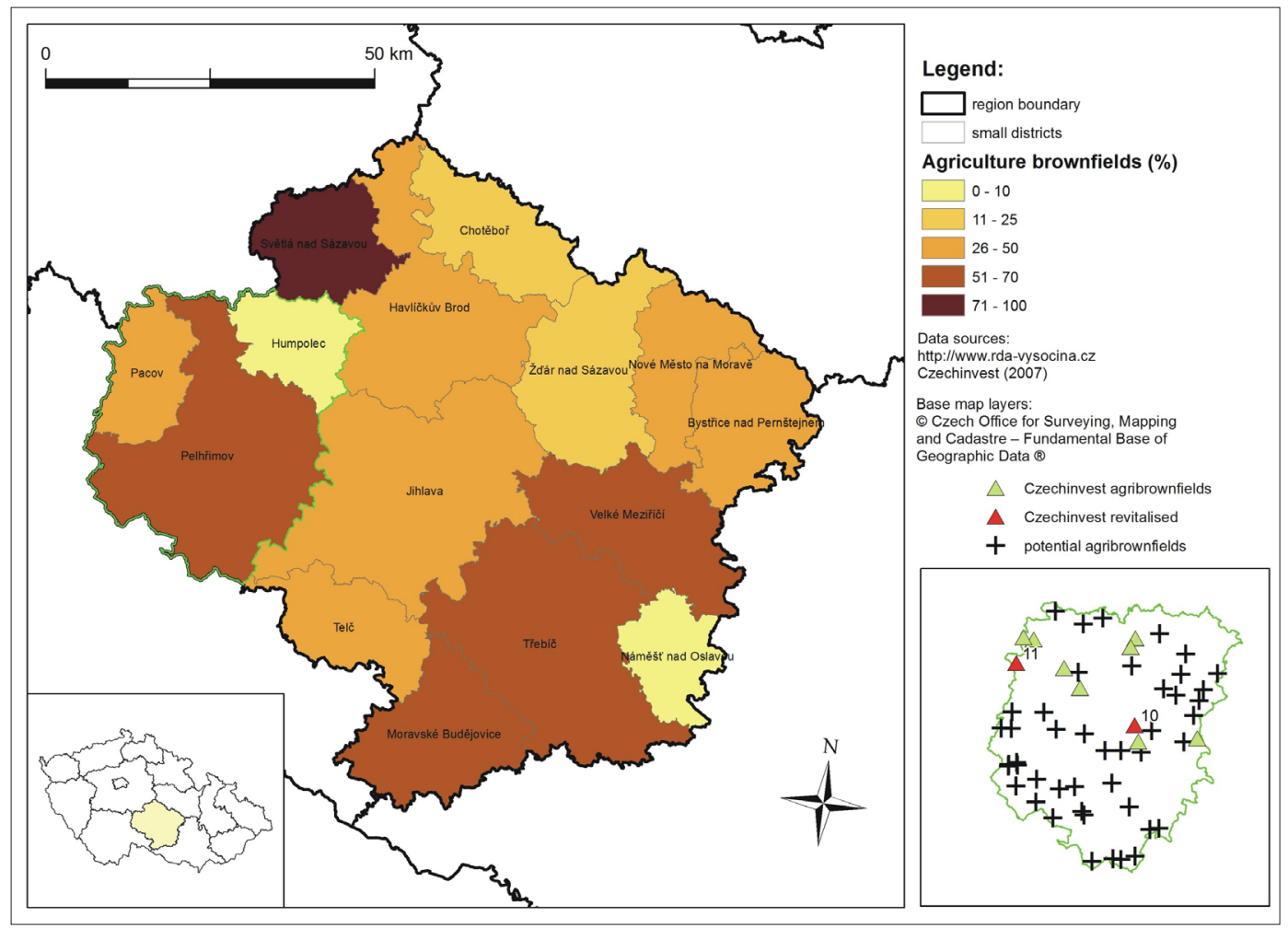

Fig. 5: Micro-regional and local differentiation of agricultural brownfields in the Vysočina Region

\subsection{Revitalization of agricultural brownfields}

Therevitalization of brownfields bringsaboutadditional costs according to the economic and political imbalance between brownfields and greenfields projects, the additional costs covering environmental loads and structural matters. The favourable localization of urban brownfields can partially compensate for any additional costs thanks to the advantage of their typically prominent position (Bardos et al., 2001), contrary to rural brownfields that are usually situated in marginal locations away from developing trends (commercial, production, residential). It is important that the issue of disadvantaged (i.e. commercially, spatially, environmentally) brownfields is incorporated into the priorities of local, regional and national strategies. Optional re-use of agricultural brownfields is affected by the current condition of the site - in the positive (use of existing infrastructure) as well as in the negative sense (incidence of ecological load, technical conditions of buildings). According to the Czechinvest study (2007), a change of use in the future is typical of agricultural brownfields; only a very small part of the originally agricultural brownfields is repeatedly used for agricultural purposes. Farm buildings are usually unsuitable for agricultural use given the process of modernization or specialization in agriculture (Birkkjaer, Pedersen, 1996).

Verhoeve et al. (2012) and van der Vaart (2005) discussed the processes of diversification in the rural economy with re-use of rural buildings by non-agricultural entrepreneurs in the BENELUX region. The most common new use were residences or non-agrarian use by the service sector (trade or commercial companies, landscapers, transport companies) or woodworking companies. This re-use is changing not only the rural economy but also social structures and spatial and environmental quality (Verhoeve et al., 2012). Mackovič (2003) describes some of possible reasons for changes in the future use of the original farm buildings in the Czech Republic. According to him, the reasons include: imbalance in the supply of agricultural objects over actual demand, the vague position of agriculture in the society, general forces of the spatial diversification of residential and agricultural functions of settlements, territorially-technical limitation of the re-utilisation and modernization of agricultural facilities within built-up areas, problematic returns on investments in agriculture or complicated proprietary rights. Jaarsma and de Vries (2013) explore consequences of the abandonment of farm buildings and their new economic use for traffic on minor rural roads, emphasizing the necessity of spatial planning for rural shrinkage processes.

The existing capacities (including under-used buildings and localities) in rural areas contribute to a significant potential for the diversification of activities in the Czech countryside (Hron, 2007). The countryside is becoming a multi-functional space with 
new functions connected with non-agrarian functions and especially agro-tourism (Sharpley and Vass, 2006). Agricultural brownfields situated in favourable localities (production areas, growth zones, suburbs) can be used for industrial, residential or public service functions and their geographical position is a crucial factor for their re-use potential. Agricultural utilization of brownfields can lead to conventional agriculture (livestock and plant production) or to alternative agriculture (organic agriculture, agrotourism). Unemployed farms can be used for other functions including modern technologies (composting plant, biogas station) or in the sector of renewable energy production (solar parks) (Adelaja et al., 2010). However, the acceptability of non-agrarian functionalities in rural areas and their effect on future spatial planning in rural space is currently a moot issue (Verhoeve et al., 2012; Jaarsma, de Vries, 2013).

The Czechinvest (2007) localities in the three small districts in our case studies were revised for their actual state and the revitalized former brownfields were analyzed to show the development of agricultural brownfields recorded by Czechinvest (localities are marked with red triangle in the maps). Characteristics of the sites are depicted in Tab. 1. The trends of a shift in future utilization were confirmed in the study. The residential and service economy sectors are the main re-use strategies; however, some other future uses were observed - a small photovoltaic power station (Opatov) or a public gallery (Těchobuz). Successfully revitalized former agri-brownfields are usually located in builtup areas, more often brownfields with buildings from the period before the socialist collectivization. Settled proprietary rights (non-fragmented ownership, clear ownership rights) were the common feature of revitalized localities.

\subsection{Institutional framework for using agricultural brownfields}

In the Czech Republic, the support for brownfields redevelopment is implemented on the basis of two operational programme types - sector operational programmes (SOPs) and regional operational programmes (ROPs). SOPs deal with the issue of brownfields from the aspect of responsible authority priorities (business supporting, environmental risks, rural development), and ROPs reflect regional specifics and needs (NUTS II regions). The sector operational programmes available for agricultural brownfields redevelopment support are listed in Tab. 2.

Future use is a crucial determinant of funding possibilities for brownfield revitalization from public funds. Basic programme synergies are defined in the National Strategic Reference Framework of the Czech Republic 2007-2013. SOP Enterprise and innovation covers the projects of re-using brownfields for the purposes of production and business; SOP Rural development covers brownfields intended for agricultural re-use. ROPs are intended to serve primarily as subsidiary complements to SOPs, especially in activities the support of which is more effective at a regional level. Questions of jurisdiction concerning the use of modern renewable energy resources are addressed through agreements concluded by central authorities. The SOP Rural Development supports biomass treatment as an extension of agricultural production.

\begin{tabular}{|c|c|c|c|c|c|c|}
\hline No. & Locality & District & Ownership & Situation & History & Use \\
\hline 1 & Podbořanský Rohozec & Louny & private limited company & built up area & historical & non-agricultural \\
\hline 2 & Milčeves & Louny & private limited company & built up area & historical & agricultural \\
\hline 3 & Solopysky & Louny & private & built up area & historical & non-agricultural \\
\hline 4 & Březno & Louny & private & built up area & historical & non-agricultural \\
\hline 5 & Malnice & Louny & private & built up area & historical & non-agricultural \\
\hline 6 & Blažim & Louny & private + public (munic.) & built up area & historical & non-agricultural \\
\hline 7 & Chlumčany & Louny & private & built up area & historical & non-agricultural \\
\hline 8 & Charvátce & Louny & private & built up area & historical & non-agricultural \\
\hline 9 & Hrádek & Louny & private & built up margin & historical & agricultural \\
\hline 10 & Pelhřimov & Pelhřimov & private limited company & suburb & socialist & non-agricultural \\
\hline 11 & Těchobuz & Pelhřimov & public (municipality) & built up area & historical & non-agricultural \\
\hline 12 & Petrušov & Svitavy & private & open landscape & socialist period & non-agricultural \\
\hline 13 & Gruna & Svitavy & private & built up area & historical & non-agricultural \\
\hline 14 & Korouhev & Svitavy & agricultural cooperative & built up margin & socialist & agricultural \\
\hline 15 & Opatov & Svitavy & private limited company & open landscape & socialist & non-agricultural \\
\hline
\end{tabular}

Tab. 1: Selected characteristics of revitalized agricultural brownfields 


\begin{tabular}{|c|c|c|c|}
\hline SOP & Provider & Priority Axis & Specific Prerequisite \\
\hline $\begin{array}{l}\text { ENTERPRISE } \\
\text { AND INNOVATIONS }\end{array}$ & $\begin{array}{l}\text { Ministry of Industry } \\
\text { and Transport of the CR }\end{array}$ & $\begin{array}{l}\text { Priority Axis No. } 5 \text { - Environment } \\
\text { for enterprise and innovation }\end{array}$ & $\begin{array}{l}\text { future use restricted to manufacturing, } \\
\text { research and development projects, } \\
\text { technology centres or business support } \\
\text { services centres }\end{array}$ \\
\hline ENVIRONMENT & $\begin{array}{l}\text { Ministry of the } \\
\text { Environment of the CR }\end{array}$ & $\begin{array}{l}\text { Priority Axis No. } 4 \text { - Improvement } \\
\text { of Waste Management and } \\
\text { Rehabilitation of Old Ecological } \\
\text { Burdens }\end{array}$ & $\begin{array}{l}\text { severely contaminated localities of Old } \\
\text { Ecological Burdens }\end{array}$ \\
\hline ENVIRONMENT & $\begin{array}{l}\text { Ministry of the } \\
\text { Environment of the CR }\end{array}$ & $\begin{array}{l}\text { Priority Axis No. } 6 \text { - Improving the } \\
\text { State of Nature and the Landscape }\end{array}$ & $\begin{array}{l}\text { brownfields reclamation in conservation } \\
\text { areas, reclamation of the biological } \\
\text { value of idle areas - revegetation of } \\
\text { brownfields in settlements }\end{array}$ \\
\hline RURAL DEVELOPMENT & $\begin{array}{l}\text { Ministry of Agriculture } \\
\text { of the CR }\end{array}$ & $\begin{array}{l}\text { Priority Axis No } 1 \text { - Improving the } \\
\text { competitiveness of agricultural, } \\
\text { food and forestry sectors - } \\
\text { modernization of agricultural } \\
\text { holdings with emphasis on } \\
\text { brownfields utilization }\end{array}$ & $\begin{array}{l}\text { municipalities with up to } 2,000 \\
\text { inhabitants } \\
\text { agricultural brownfields }\end{array}$ \\
\hline RURAL DEVELOPMENT & $\begin{array}{l}\text { Ministry of Agriculture } \\
\text { of the CR }\end{array}$ & $\begin{array}{l}\text { Priority Axis No. } 3 \text { - Improving the } \\
\text { quality of life in rural areas and } \\
\text { encouraging the diversification of } \\
\text { economic activities }\end{array}$ & $\begin{array}{l}\text { municipalities with up to } 500 \\
\text { inhabitants }\end{array}$ \\
\hline RURAL DEVELOPMENT & $\begin{array}{l}\text { Ministry of Agriculture } \\
\text { of the CR }\end{array}$ & $\begin{array}{l}\text { Priority Axis No. } 4 \text { LEADER } \\
\text { - partnership projects of rural } \\
\text { development }\end{array}$ & $\begin{array}{l}\text { partnership projects - LEADER project } \\
\text { rules }\end{array}$ \\
\hline
\end{tabular}

Tab. 2: Sector operational programmes available for redevelopment of agricultural brownfields in the Czech Republic Source: www.mze.cz, www.mpo.cz, www.mzp.cz, www.czechinvest.org

\section{Conclusion}

Soil is regarded as a renewable natural resource and further soil appropriation is inconsistent with the principles of sustainable development. Revitalization of brownfields is considered an active implementation of soil protection. Abandonment of agricultural farms is a widespread European issue; however, the transformation shift from collective to individual agriculture in the former socialist countries in Europe determined specific conditions for the abandonment of agricultural buildings and their future evolution. The duality between the traditional agricultural building of architectural and aesthetic quality and agricultural objects from the period of large-scale socialist agricultural production, is seen conspicuously in the former socialist countries. Similar trends of rural economy diversification with the re-use of rural buildings for non-agricultural activities described from Western Europe were recorded also in the Czech model regions. However, successfully revitalized former agribrownfields are usually located in built-up areas, brownfields are more often revitalized with buildings from the period before the socialist collectivization and in localities with settled proprietary rights. A solution remains to be found for idle agricultural objects from the period of large-scale socialist agricultural production. It is important to incorporate the issue of disadvantaged (i.e. commercially, spatially, environmentally) brownfields in the priorities of local, regional and national strategies for the regeneration of brownfields and spatial planning in rural areas.

One half of brownfields (48.6\%) is located in municipalities with up to 2,000 inhabitants (simplified definition of countryside) in the Czech Republic. Thus, rural brownfields are considered as vacant capacities that can be utilized for the diversification of activities in Czech rural areas. Agricultural brownfields are the most frequently occurring brownfields in the Czech Republic (35\%) and especially in some regions (Olomouc and Zlín Regions). However, their area share (18\%) indicates their spatial position in the landscape - the agricultural brownfield sites are very abundant but cover only small areas. The regional differentiation of agricultural brownfields is increasing with geographic scale and is conditioned by factors much similar to the processes of cropland abandonment in the postsocialist countries of Eastern Europe, particularly by natural conditions for agriculture (soil productivity, relief) and by socioeconomic factors (urbanisation rate, a region's economic structure).

A crucial step in the revitalization of brownfields is their stable identification and inventory. The inventory of brownfields entails a range of methodological difficulties, including the deficient 
legislative framework and the lack of central holistic approach. Although the valuable Czechinvest database (2007) registered 2,355 brownfield localities, the estimated number of brownfield sites ranges between 8,500 and 11,700. Thus, other potential information sources should be used to supplement the record of brownfields. Potential information sources and potential methodological tools for the identification of agricultural brownfields are suggested in this study. The institutional framework is presented for the utilization of brownfields of agricultural origin. Funding programmes for the revitalization of agri-brownfields are available in the Czech Republic. Future utilization is a crucial determinant of the funding possibilities for the revitalization of brownfields from public funds. The strategy for the reclamation of agricultural brownfields is primarily embedded in the Rural Development SOP, however the
Regional Operational programmes can better reflect the composition of regional brownfields and hence urgency of redevelopment and priorities of regions. The re-use of former agricultural buildings is changing not only the rural economy, but also the social structure and spatial and environmental quality (Verhoeve et al., 2012), and this is why the consequences of the emergence of agricultural brownfields are a relevant research topic as well as one of practical importance.

\section{Acknowledgement}

This study was supported by the Ministry of Agriculture of the Czech Republic - Institutional research plan No. MZE0002704902 - Integrated systems of protection, improvement and use of soil, water and landscape in agriculture and rural development.

\section{References:}

ADELAJA, S., SHAW, J., BEYEA, W., MCKEOWN, J. D. C. (2010): Renewable energy potential on brownfield sites: A case study of Michigan. Energy Policy Vol. 38, No. 11, p. 7021-7030.

BARDOS, P. R., MARIOTTI, C., MAROT, F., SULLIVAN, T. (2001): Framework for decision support used in contaminated land management in Europe and North America. Land Contamination \& Reclamation, Vol. 9, No. 1, p. 149-163.

BARTƯŠKOVÁ, J., HOMOLKA, J. (2009): Analysis of land-law relations development in the Czech Republic after 1989 in the legal and economic context. Agriculture Economics - Czech, Vol. 55, No. 5, p. 250-256.

BENAYAS, J. M. R., MARTINS, A., NICOLAU, J. M., SCHULZ J. J. (2007): Abandonment of agricultural land: an overview of drivers and consequences. Perspectives in Agriculture, Veterinary Science, Nutrition and Natural Resources, Vol. 2, No. 57, 14 pp.

BIČÍK, JELEČEK, L., ŠTĚPÁNEK, V. (2001): Land-Use Changes and Their Social Driving Forces in Czechia in the 19th and $20^{\text {th }}$ Centuries, Land Use Policy, Vol. 18, No. 1, p. 65-73.

BIRKKJAER, K. O., PEDERSEN, S. (1996): Re-use of old rural buildings in Denmark In: New Uses for Old Rural Buildings in the Context of Landscape Planning. Proceedings of The International Seminar of the Second Technical Section of C.I.G.R., Universita Cattolica Del Sacro Cuore, Piacenza, 1996, p. 139-144.

CZECHINVEST (2007): Vyhledávací studie pro lokalizaci brownfieldů. Praha. Available at: www.czeinvest.org (access: July 2010).

DOUCHA, T., FOLTÝN, I. (2008): Czech agriculture after the accession to the European Union - impacts on the development of its multifunctionality. Agriculture Economics - Czech, Vol. 54, No. 4, p. 150-157.

DVORSKÁ, A., SIR, M., HONZAJKOVÁ, Z., KOMPRDA, J., ČUPR, P., PETRLÍK, J., ANAKHASYAN, E., SIMONYAN, L., KUBAL, M. (2012): Obsolete pesticide storage sites and their POP release into the environment-an Armenian case study. Environmental Science and Pollution Research, Vol. 19, No. 6, p. 1944-1952.

FUENTES, J. M. 2010. Methodological base for documenting and reusing vernacular farm architecture. Journal of Cultural Heritage, Vol. 11, No. 2, p. 119-129.

GARCIA, A. I., AYUGA, F. (2007): Reuse of abandoned buildings and the rural landscape: The situation in Spain. Transactions of the American Society of Agricultural and Biological Engineers, Vol. 50, No. 4, p. 1383-1394.

HOWLAND, M. (2004): The role of contamination in central city industrial decline. Economic Development Quarterly, Vol. 18, No. 3, p. 207-219.

HRON, J., ŠTƯSEK, J., ARNOŠT, M., HUML, J., PLATILOVÁ-VORLÍČKOVÁ, L. (2007): Diversification - strategy of building the competitive advantage in agribusiness. Agriculture Economics - Czech, Vol. 53, No. 12, p. 580-584.

HUDEČKOVÁ, H. (1995): Privatizace v zemědělství a obnova venkova. Czech Sociological Review, Vol. 31, No. 4, p. 449-462.

IOFFE, G., NEFEDOVA, T., ZASLAVSKY, I. (2004), "From Spatial Continuity to Fragmentation: The Case of Russian Farming," Annals of the Association of American Geographers, Vol. 94, No. 4, p. 913-943.

JAARSMA R. F., VRIES, J. R. de (2013): Former farm buildings reused as rural villa, building contractor or garden centre: consequences for traffic flows on minor rural roads in a changing countryside. European Countryside Vol. 5, No. 1, p. 8-51. 
MACKOVIČ, V. (2003): Vybrané aspekty zemědělské výstavby ve venkovském prostoru. Urbanismus a Územní Rozvoj, Vol. 4, No. 5, p. 2-12.

NOE, E., ALRRE, H. F., LANGVAD, A. M. (2008): A polyocular framework for research on multifunctional farming and rural development. Sociologia Ruralis, Vol. 48, No. 1, p. 1-15.

PAGE, G. W.; BERGER, R. S. (2006): Characteristics and land use of contaminated brownfield properties in voluntary cleanup agreement programs. Land Use Policy, Vol. 23, No. 4, p. 551-559.

PRISHCHEPOV, V. A., RADELOFF, V. C., BAUMANN, M., KUEMMERLE, T., MÜLLER, D. (2012): Effects of institutional changes on land use: agricultural land abandonment during the transition from state-command to market-driven economies in post-Soviet Eastern Europe, Environmental Research Letters, Vol. 7, No. 2, 13 pp.

PRISHCHEPOV, A. V., MUELLER, D., DUBININ, M., BAUMANN, M., RADELOFF, V. C (2013): Determinants of agricultural land abandonment in post-Soviet European Russia. Land Use Policy, Vol. 30, No. 1, p. 873-884.

RUDA, G. (1998): Rural buildings and environment. Landscape and Urban Planning, Vol. 41, No. 2, p. $93-97$.

SHARPLEY, R., VASS, A. (2006): Tourism, farming and diversification: an attitudinal study. Tourism Management, Vol. 27, No. 5, p. 1040-1052.

SCHOENBAUM, M. (2002): Environmental contamination, brownfields policy, and economic redevelopment in an industrial area of Baltimore, Maryland. Land Economics, Vol. 78, No. 1, p. 60-71.

SVOBODOVÁ, H., VĚŽNÍK, A. (2009): To the problems of agricultural brownfields in the Czech Republic - Case study of the Vysočina region. Agriculture Economics - Czech, Vol. 55, No. 11, p. 550-556.

TASSINARI, P., TORREGGIANI, D., BENNI, S., DALL'ARA, E. (2010): Research model for farm building design: General structure and physiognomic characterization phase. CIGR Journal, Vol. 12, No. 1, p. 47-54.

VAN DER VAART, J. H. P. (2005): Towards a new rural landscape: consequences of non-agricultural re-use of redundant farm buildings in Friesland. Landscape and Urban Planning Vol. 70, No. 1-2, p. 143-152.

VAN MEIJL, H, VAN RHEENEN, T, TABEAU, A, EICKHOUT, B. (2006): The impact of different policy environments on agricultural land use in Europe. Agriculture, Ecosystems and Environment, Vol. 114, No. 1, p. 21-38.

VERHOEVE, A., DE ROO, N., ROGGE, E. (2012): How to visualize the invisible: Revealing re-use of rural buildings by nonagricultural entrepreneurs in the region of Roeselare-Tielt (Belgium). Land Use Policy, Vol. 29, No. 2, p. 407-416.

www.mze.cz

www.mpo.cz

www.mzp.cz

www.czechinvest.org

www.mapy.cz

www.zanikleobce.cz

www.sekm.cz

\section{Authors'addresses:}

Mgr. Jan SKÁLA; e-mail: skala.jan@vumop.cz

Doc. Ing. Radim VÁCHA, PhD., e-mail: vacha.radim@vumop.cz

Ing. Jarmila ČECHMÁNKOVÁ, e-mail: cechmankova.jarmila@vumop.cz

Ing. Viera HORVÁTHOVÁ, e-mail: horvathova.viera@vumop.cz

Research Institute of Soil and Water Conservation

Žabovřeská 250, 15627 Prague 5, Czech Republic

Initial submission 10 November 2012, final acceptance 25 May 2013

Please cite this article as:

SKÁLA, J., ČECHMÁNKOVÁ, J., VÁCHA, R., HORVÁTHOVÁ, V. (2013):Various aspects in the genesis and perspectives of agricultural brownfields in the Czech Republic. Moravian Geographical Reports, Vol. 21, No. 2, p. 46-55 